\title{
ECHOES OF THE VISION OF HINDU PHILOSOPHY IN T. S. ELIOT'S WRITINGS
}

\author{
Damauru Chandra Bhatta*
}

\section{ABSTRACT}

This paper makes an attempt to explore the echoes of the vision of Hindu philosophy in the selected works of T. S. Eliot. The works of Eliot such as his primary essay "Tradition and the Individual Talent," and his primary poems such as "The Love Song of J. Alfred Prufrock," "Gerontion," The Waste Land, "Ash Wednesday," "A Song for Simeon" and Four Quartets are under scrutiny in this paper. Eliot's primary texts echo the vision of the Upanishads, the Bhagavad-Gita and the Patanjali Yoga Sutras of the Hindu (Vedic) philosophy. The vision is that rebirth is conditioned by one's karma (actions). No one can escape from the fruits of his karma. One needs to undergo the self-realization to know the Essence (Brahman). When one knows the Essence, he is liberated from the wheel of life and death. Man himself is Brahman. The soul is immortal. The basic essence of Hindu philosophy is non-dual, which says that all the living beings and non-living objects are the manifestations of the same Ultimate Reality (Brahman). Eliot suggests that the knowledge of this essence can help humanity to promote equality and justice by ignoring discrimination and duality, to end human sorrows and to achieve real peace and happiness. This finding can assist humanity in the quest for understanding the meaning of human existence and the true spiritual nature of life to address the human sorrows resulted from the gross materialistic thinking.

Keywords: Upanishad, karma, knowledge, bondage, wheel, liberation, Essence, the still point, non-dual.

\section{INTRODUCTION}

T. S. Eliot (1888-1965) is one of the prominent poets of the twentieth century in the West. His essays, poems, plays, and literary and social criticisms echo the spiritual vision of Hindu philosophy. He is a visionary poet, who helped to spread the Hindu (Vedic) philosophy in the West.

* Mr. Bhatta is an Associate Professor, Tri-Chandra Multiple Campus, Ghantaghar, TU. 
Professor Harry Oldmeadow (2004) writes that in 1911, Eliot joined Harvard University for three years of intensive postgraduate study. He studied Sanskrit, Pali, Hindu philosophy (especially, logic, ethics and metaphysics, and Patanjali's Yoga Sutras), and the religious system of China (Taoism) and Japan (Zen). Eastern philosophy and metaphysics impressed him for life-long. This shaped his spiritual development, poetic vision and method. This left him with "enlightened mystification," helping him to escape from the Western intellectual prejudices and spiritual growth of his own time with which he was not satisfied (p. 30).

The works of Eliot (1980) under investigation in this paper are his primary essay "Tradition and the Individual Talent," and his primary poems such as "The Love Song of J. Alfred Prufrock," "Gerontion," and The Waste Land, which consists of "The Burial of the Dead," "A Game of Chess," "The Fire Sermon," "Death by Water" and "What the Thunder Said." Likewise, "Ash Wednesday," "A Song for Simeon" and Four Quartets, which consists of "Burnt Norton," "East Coker," "The Dry Salvages" and "Little Gidding" are also under investigation.

The search of the finite and transient human self for the Infinite and the Eternal Self in "a wilderness of mirrors" ("Gerontion," Eliot, 1980, p. 23) haunts much of Eliot's primary poems as mentioned above. "The Love Song of J. Alfred Prufrock" is a representation of the modern man, his futile materialistic thinking, his fragmented and anxious state of mind and his own uncertain identity. "Gerontion" shows the spiritual aridity of urban culture and Eliot's disbelief in Christian faith. The Waste Land depicts material richness but spiritual hollowness and the loss of the belief in religion and spirituality of the wastelanders. "The Burial of the Dead" shows impermanence, transitoriness, changeability and suffering. "A Game of Chess" shows the never satisfying dirty sexual desires. "The Fire Sermon" shows the need of detachment from lust for a peaceful and happy life. "Death by Water" shows the vanity of human wishes and the meaninglessness of human vanities. Similarly, "What the Thunder Said" shows the need of spiritual values for spiritual transformation or rebirth. When a man achieves the knowledge of spirituality, he is reborn. "Ash Wednesday" is related to Eliot's conversion into Anglo-Catholicism, the pain of accepting religion at the cost of his disbelief and a call for spiritual awareness and disillusionment. This is an autobiographical poem, which shows his struggle to detach himself from the temptations of the phenomenal world for the enlightenment of the Essence. "A Song for Simeon" expresses Eliot's thirst for liberation. 
Likewise, Four Quartets, which consists of four poems such as "Burnt Norton," "East Coker," "The Dry Salvages" and "Little Gidding," meditates on the themes of spiritual awareness and the Essence or the Reality of life. "Burnt Norton" moves around the subject of temporal time and eternity (eternal Time). "East Coker" reflects on the eternal cycle of life and death of every being and object and the need of devotion (Bhakti). "The Dry Salvages" focuses on the need of having devotion for Enlightenment. Similarly, "Little Gidding" presents the principle of non-dual philosophy and the need of the path of knowledge to realize the Essence of life to be free from the bondage of life and death permanently.

Eliot turned to the primitive wisdom in his poems such as in The Waste Land and Four Quartets "as a way of reapproaching and rediscovering the basis of a Christian vision for a secularized Western society" (Moody, 2008, p. 19). That basis should be the Hindu philosophy such as the Upanishads and the Bhagavad-Gita, as suggested by Eliot. People have forgotten and rediscovered the primitive wisdom repeatedly. Now, they have again forgotten the wisdom in the modern time. They have to do labor to regain it for the benefit of humankind. Therefore, Eliot (1980) says, "There is only the fight to recover what has been lost / And found and lost again and again" ("East Cocker," p. 128).

Eliot's vision is a response to the human predicament. His writings show his personal quest for understanding the meaning of human existence and the true spiritual nature of life to address the human sorrows born out of the sheer materialistic thinking.

The basic theoretical insights of Hindu philosophy are the principles of rebirth according to our karma, the illusion of death and the reality of immortality, the immortality and eternity of the soul, the need to transcend materiality for the self-realization of Brahman (the Essence/the Reality), the journey from bondage to liberation, the unity of Ataman (the self) and Brahman (the Universal Self) and the spiritual unity in diversity in the world. The non-dual philosophy of the mainstream says that we need not die for liberation. When we have the knowledge of Brahman (the Essence/the Reality), we are liberated from the cycle of life and death, or pleasure and pain while alive. Heaven and hell are within us and around our life. Eliot's works echo these spiritual and philosophical visions of Hindu philosophy. This is the major argument for writing this paper. 


\section{OBJECTIVES}

(1) To explore the echoes of the vision of Hindu philosophy in his writings such as his poems The Waste Land and Four Quartets, and his essay "Tradition and the Individual Talent," and

(2) to reflect on the significance of those echoes of the Hindu philosophy such as the Upanishads, the Bhagavad-Gita and the Patanjali Yoga Sutras in his writings.

\section{ANALYSIS}

\section{Echoes of Hindu Philosophy}

Eliot suggests that selflessness or disinterestedness facilitates the path to the self-realization through the impersonal poetic vision. In this regard, the Upanishads express that Brahman creates and causes changes in the world but who Himself remains unchanged (Brihadaranyaka 4.5.15; Maitri 2.7; Shvetashvatara 3.2). This concept is similar to Eliot's concept of the catalyst envisioned in his famous essay "The Tradition and the Individual Talent" in The Sacred Wood, in which Eliot (1980) declares, "Poetry is not a turning loose of emotion, but an escape from emotion; it is not the expression of personality, but an escape from personality" (pp. 5253). He suggests that poet should be like a catalyst, the element that changes the others but remains itself unchanged. This view of poetry is influenced by the Upanishadic philosophy that actors/doers or their actions should be selfless, disinterested, impersonal or depersonalized. This suggests that selflessness, disinterestedness or impersonality does not mean apathy or indifference. This means that works should be performed with attention as one's duty but without being entangled in them. Entanglement blocks the progress of spiritual life. Like Brahman and the catalyst, the poet should remain unaffected emotionally. Poetry should not be colored by the poet's emotions and personality.

Eliot treats time both as a temporary element and as an everlasting element, Time. In this regard, Maharshi Patanjali's Yoga Sutras 4.12-14 expresses that both past and future exist within the object at all times. There is a unity in all objects (Prabhavananda \& Isherwood, pp. 155-156). Similarly, in "Burnt Norton," Eliot (1980) echoes Yoga Sutras. 
Time present and time past

Are both perhaps present in time future,

And time future contained in time past.

If all time is eternally present

All time is unredeemable. (p. 117)

This suggests that time is single. It is an unbroken series of events. Time is eternal. But for ordinary people there is the existence of three times - past, present and future. Past, present and future are eternal times. Past and present become future. Indeed, the past is the future. The past is the cause of the effect (future). Therefore, past and present contain future. If so, both past and present are in future. Present also contains both past and future in its womb. We cannot be completely free from the past because the present carries the past. All time (past, present and future) are merely sequences of a single movement when viewed from a higher level. From this viewpoint, time is One. It is a single unbroken unity. If time is considered as a temporary moment, it is not eternal. If time is considered as Brahman, it is eternally present. Eliot does not make this idea clear here. Eliot simply says above that "all time is eternally present" but he does not clarify in what sense it is so. In this connection, Smidt's citation to Bergson's theory of time is worth mentioning. Here Smidt (2016) says, "Bergson's theory of time [is]: "All time is eternally present" (p. 133).

To Eliot, consciousness (intelligence; Brahman) is Shakti (Force, Power, Energy or Goddess), which is achieved by Bhakti. Shakti is the power of Brahman. Shakti is generally hidden or unseen but She acts through bodies and this universe. The great non-dual sages such as Raman Maharshi, Abhinavagupata, Shankarcharya, Ramkrishna and many great Christian non-dualists such as the Saint John of the Cross were secret worshippers of the consciousness of the divine as mother, as goddess or as feminine. Very often, they loved the Goddess of consciousness in secret, especially Shankaracharya did so. Shakti is worshipped as Goddess with Bhakti (humility or devotion) in Hindu religion. Goddess-worship is the path to bliss. According to the Chhandogya Upanishad 1:1:10, what one does with "knowledge, faith and meditation becomes more powerful" (Radhakrishnan, 2012, p. 339) and changes into Shakti. Regarding Bhakti, in "East Cooker," Eliot (1980) opines, "The only wisdom we can hope to 
acquire / Is the wisdom of humility: humility is endless" (p. 126). Humility is Bhakti. Bhakti is Brahman, who is endless. Brahman and Shakti are inseparable like fire and its heat. Here, Eliot suggests the need of the knowledge of and devotion to the formless non-dual Brahman for the attainment of His grace through which we can know Him truly. This echoes the Mundaka Upanishad 3:2:3.

Humility is concerned with humbleness. Being humble by losing one's pride of knowledge, complete surrender and extreme self-sacrifice are means to attain Brahman. Where there is pride, there is no Bhakti, without which it is impossible to have the grace and knowledge of "the still point" (Brahman). Those who are proud of their knowledge cannot know Him in reality. They do not know the Reality due to their ignorance. Similar idea Eliot (1980) reveals in "East Cocker": "And what you do not know is the only thing you know / And what you own is what you do not own / And where you are is where you are not" (p. 127). What the people of false pride suppose to be right is wrong. What they suppose to be right is wrong. What they suppose to be theirs is not theirs. Where they suppose to be is wrong.

Here, Eliot suggests that the people proud of their vanities are ignorant since knowledge disappears where there is no humility. Defining the term "ignorance," Maharshi Patanjali says, "To regard the non-eternal as eternal, the impure as pure, the painful as pleasant and the non-Atman as the Atman - this is ignorance" (Prabhavananda \& Isherwood, 2:5, p. 74). Those who say that they know Brahman do not know Him really but those who say that they do not know Him know Him really. Those who have the boast of their knowledge cannot know Him really. In fact, those who know Him cannot express Him in words. Understanding Brahman is only a matter of self-realization. This is expressed by the Kena Upanishad 2:3:

To whomsoever it [the Supreme Brahman] is not known, to him it is known: to whomsoever it is known, he does not know. It is not understood by those who understand it; it is understood by those who do not understand it. (Radhakrishnan, 2012, p. 585)

The concept of time, with a tone of the Advait Vedant (the nondual Hindu philosophy), is found in Eliot's poetry. The Shvetashvatara Upanishad expresses that the source of time and everything is Brahman. 
Everything - what was in the past, what will be in the future and what is now-is Brahman (3:15). There was no time-space continuum before the creation. In this connection, the Brihadaranyaka Upanishad says that there was only Brahman before the creation (1.4.1). Sounding similar to the Upanishads, Eliot (1980) says in "Little Gidding," "What we call the beginning is often the end / And to make an end is to make a beginning. / The end is where we start from" (p. 144). Here, Eliot says that beginning is the end and the end is the beginning. Here, what Eliot suggests that the beginning and the end are the same. The last part of the beginning is the end and the last part of the end is the beginning. They are like the two sides of a coin, inseparable from each other. Their original source is Brahman. Both processes of the time are indeed Brahman. Both originate from and end in Brahman.

With a message of doing karma (action) selflessly as told by Krishna to Arjuna in the Bhagavad Gita (2.47), Eliot (1980) mentions in "East Cocker": "For us there is only the trying. The rest is not our business" (p. 128 ) because the Gita (2.27) declares, "Death is certain for everyone who is born, as rebirth is sure of everyone who is dead" (Baidya, 2014, p.65). In "East Cooker," Eliot (1980) expresses his conviction for this: "In my beginning is my end . . . . In my end is my beginning." In the beginning (birth) is the end (death) and in the end is birth. Beginning comes with its end in itself. This suggests the circularity of life and time. In fact, from the viewpoint of the principal Upanishads, there is no death. Death is an illusion. Immortality is a reality. The soul is immortal and eternal. There is no permanent death even of the body. The body is made of five elements. They just transform from one form to another form, from one body to another body or from one place to another place when the soul leaves the body. The elements just disappear but are not destroyed permanently after death.

Eliot believes in the principle of selfless karma (action) without attachment. In the Bhagavad Gita, Lord Krishna admonishes Arjun to work everything as one's duty but without expecting its fruit (2.47). Therefore, Eliot (1980) in "The Dry Salvages," advises, "And do not think of the fruit of action. / Fare forward (p. 134). Here, Eliot does not mean that we should not enjoy the fruit of the karma. The fruit of the karma is inevitable. He 
means to say that worrying for the future-result hampers our activities. We should move ahead to accomplish our karma with interest and accept its result, too. We should not stop doing karma. That is very dangerous for the welfare of humanity.

Eliot stresses the need for the refinement of the soul to be free from despair and death. Maharshi Patanjali's revelation in his Yoga Sutras 3.56, 4.6 is: "Perfection is attained when the mind becomes as pure as the Atman itself"; "Of the various types of mind, only that which is purified by 'samadhi' is freed from all latent impressions [vaasanaa, sanskaara] of karma and from all cravings" (Prabhavananda \& Isherwood, pp. 146, 151). In this line of argument, in "Little Gidding," Eliot (1980) asserts, "The only hope, or else despair lies in the choice of pyre or pyre - to be redeemed from fire by fire" (p. 144). Hope or despair depends upon our constructive or destructive activities. We can be free from the fire of lust, desire, anger, avarice, infatuation, delusion, ego, jealousy, passion and enmity from the fire of knowledge.

Eliot has interest in the principle of karma and rebirth. Patanjali Yoga Sutras 4.9 says, "Because of our memory of past tendencies, the chain of cause and effect is not broken by change of species, space or time" (Prabhavananda \& Isherwood, p. 154). Its echo is found in Eliot's (1980) The Cocktail Party:

EDWARD: I see that my life was determined long ago

And that the struggle to escape from it

Is only make-believe, pretence

That what is, is not, or could be changed. (Act I, Scene 2, p. 326)

This expresses that no one can escape from the destiny, which is determined by karma in the past. This is somewhat similar to the principle of the chain of cause and effect of science. The chain of cause and effect is the Law of Karma, according to which we move on the cycle of life and death as per our karma, good or bad. Our present life is a result of our past lives' karma (actions).

Eliot is frustrated with flying passions and transitory physical pleasures. In this connection, the Katha Upanishad expresses that human beings become old and die $(1: 1: 28)$. Therefore, the enjoyment of physical 
pleasures are transitory and worthless (1.1.26). Eliot is not happy with his life because of his tragic conjugal relationship with his first wife Vivienne Haigh-Wood. In "Gerontion," Eliot (1980) loses his passions or attachment for life because of his bitter experiences surrounded by corruption, debasedness or impurity:

I have lost my passion: why should I need to keep it

Since what is kept must be adulterated?

I have lost my sight, smile, hearing, taste and touch:

How should I use them for your closer contact? (p. 23)

In fact, man loses his passions for life when life is degraded and becomes without the physical power of perceiving things and the ability to be in touch with others.

In "The Hollow Men" also Eliot (1980) has bitter experiences of life where people are morally and spiritually dead:

This is the dead land

This is Cactus land.

Here the stone images

Are raised, here they receive

The supplication of a dead man's hand

Under the twinkle of a fading star. (p. 57)

This stanza uses the metaphors such as "dead land," "cactus land," "stone image," "dead man's hand," and "a fading star." They all allude to the death of religion and spirituality in the modern urban civilization. They refer to the spiritual bareness of those who do not or cannot accept the Word of God.

Eliot thinks that liberation is only a solution to life's problems, sufferings and pain. The Ishavasya Upanishad expresses that knowledge leads one to immorality (11), which is the state of permanent release from the cycle of birth and death or pleasure and pain. Eliot is now detached and indifferent towards life because of its absurdities. Therefore, Eliot (1980) seeks liberation as in "A Song for Simon":

I am tired with my own life and the lives of those after me, I am dying in my own death and the death of those after me. 
Let thy servant depart,

Having seen thy salvation. (p. 70)

Here, Eliot is fed up with his and others' lives because he is aware of physical life's briefness and ultimate death. He suggests that when a man is spiritually dead, he is dead. He need not to die for death. Before his physical death, he wants salvation, which comes only through knowledge.

Eliot is aware of life's impermanence, change, transitoriness and sufferings. In the Upanishads, there is a discussion of life and the world in terms of impermanence and suffering. Desire is the sole cause of human sorrows. The individual self (jivatman) is caught up in the network of desires. The Maitri Upanishad 1:3-4 and the Brihadaranyaka Upanishad 3:4-5, 3:7, $3: 28,4: 4$, too, confirm human sorrows, frailty and the impermanence of life and the world. Eliot (1980) presents this picture of impermanence, change, transitoriness and suffering" in the opening lines of "East Coker" in Four Quartets:

In my beginning is my end. In succession

Houses rise and fall, crumble, are extended,

Are removed, destroyed, restored, or in their place

Is an open field, or a factory, or a bypass. (p. 123)

Here, Eliot says that creation and destruction are two inevitable phenomena of the world. Nothing can remain intact forever. House are built and destroyed. They are changed into an open field, a factory or a bypass. This alludes to the terrible situating of World War II when mass destruction and dissolution were on.

In European concept, time is linear and as such it has a beginning and an end. Therefore, time is finite. But in Hindu philosophy time is circular or cyclical. It is contemplated both as a temporary time (a symbol of death and decay) and an Eternal Time (the Death of death-mahaakaala), a symbol of liberation of the Soul. In Eliot's (1980) poems "Burnt Norton," "East Cooker," "Dry Salvages" and "Little Giddings," there is a description of the relation between the temporary time and the Eternal Time.

Similar to the thoughts of Hindu philosophy, Eliot (1980) introduces, in "Burnt Notion," the concept of "the still point" (p. 119), which is known as Atman (the self), kootastha (the Unchangeable, the Changeless, the 
Supreme Soul), parama brahman (the Supreme Brahman) or Brahman in the Upanishads. In the Vedas, "the still point" is known as stambha (the Cosmic Pillar). "The still point" is called "dhruva" in the Brihadaranyaka Upanishad 4:4:20: "This indemonstrable and constant being can be realized as one only. The self is taintless, beyond space, unborn, great and constant" (Radhakrishnan, 2012, p. 278).

Eliot (1980) defines "the still point" in various ways in his poems. The concept of "The heart of the light" ("The Burial of the Dead," p. 38), the "multifoliate rose" ("The Hollow Men," p. 58) or "the centre of the silent Word" ("Ash Wednesday," p. 65) is exactly defined as "the still point" in "Burnt Norton" (p. 119). "The still point" is Brahman/God, who is the pure actuality, the meaning (logos), in whom all possible good has existence. "The still point" is the source of eternal peace and happiness. Eliot (1980) wants us to achieve the same "still point" to end our three planes of sufferings — physical (aadhibhautika), natural (aadhidaivika) and spiritual (aadhyatmika) by chanting the mantra "Shantih shantih shantih" in "What the Thunder Said" (Four Quartets, p. 50).

Eliot thinks that we die every moment and are reborn every moment. When we live spiritually, we are reborn. If not, we die. Confirming to the inevitability of death and life, the Bhagavad Gita says that death follows birth and birth follows death (2.27). Death is simply the disappearance of the soul, not its death. There is the eternal dance of the soul's appearance and disappearance along with time, which is indicated in Eliot's (1980) poetic lines such as in "The Dry Salvages": "Time is no healer: the patient is no longer here" (p. 134) or in "The time of death is every moment" (p. 134). These lines indicate that time cannot return a dead man. The patient goes to the world of death, where is rebirth. We can die any moment.

Eliot believes that Time is ever flowing. It cannot be divided. It has no parts. Our life flows through the continual march of time. Like Maharshi Patanjali, Eliot believes that the only way to free oneself from the clutches of Time is to attain liberation. For this, one should take recourse in meditation, penance and yoga. "Emphasizing on the undisturbed calmness of mind to attain liberation," in the Yoga Sutras 1.33, Maharshi Patanjali writes, "Undisturbed calmness of mind is attained by cultivating friendliness toward the happy, compassion for the unhappy, delight in the virtuous, 
and indifference toward the wicked" (Prabhavananda \& Isherwood, p. 40). Against this background, Eliot (1980) says, "Only through time time can be conquered ("Burnt Norton," p. 120). Here, conquering time means attaining to liberation, which is possible only through time (the time spent for spiritual practices). Eliot tries to attain the changeless time, termed as Time, Eternity or Immortality, in his spiritual journey towards eternity and immortality.

The notion of the dual selves - jivatma (the self) and Paramatma (the Supreme Self) recurs in Eliot's writings. They live in our heart as the two amicable birds which live in the two branches of the same tree, as described in the Upanishads such as in the Mundaka 3:1:1-2 and Shvetashvatara 4:6-7, the concept of the twin selves - one active and worldly, the other contemplative and spiritual — of a human being is introduced by means of the symbolism of the two birds dwelling on the tree of life: one lower bird acts, while the other higher bird looks on; one eats the fruits, sweet and sour, on the lower branch, while the other watches and waits at the top-most branch. There is a veil of Maya (illusion) between the two birds. Therefore, the lower bird cannot see the higher bird. But one day, the lower bird (jivatma) becomes successful to tear the veil of Maya and identifies himself with the higher bird (Paramatma), which stands for the Eternal Self (Brahman) established in sat-chit-aananda (Existence-Knowledge-Bliss). This echoes in Eliot's (1980) poetic lines: "Go, go, go said the bird; human kind / Cannot bear very much reality" ("Burnt Norton," p. 118). Here, the higher bird makes the lower bird cautious of illusion and reality. Human beings prefer dwelling in illusion to dwelling in reality.

The things and phenomena of the world are Maya or unreal in terms of the principal Upanishads. On the ground of the Upanishads, Shakaracharya (2015), in his Vivekachudamani, says that Brahman alone is real, the world is unreal (verse 20, p. 12) in the sense that they are passing constantly far away from our eyes every moment. Similar to this idea, Eliot (1980) in The Waste Land depicts the world as "Unreal" as observed by Tiresias (pp.39, 43, 48). He sees things passing on as in the curtain of a cinema screen or the reflections passing through a mirror. He witnesses or observes things like the higher bird, which is a symbol of the detached Self. 
Eliot is aware of the materialistically rich but spiritually hollow men who are enjoying carnal pleasure but without psychological peace and happiness in the wasteland of the modern world. According to the Katha Upanishad, only the spiritually rich who can see Brahman/God inside himself can attain to the eternal peace, but not the others (2.2.13). Similarly, Eliot's (1980) "The Hollow Men" describes such people as "empty men" (p. 58). They are prey to the selfish desires and deluded by appearances.

Eliot believes that the light of knowledge dispels the darkness of ignorance and bestows unbound joy. Therefore, the Brihadaranyaka Upanishad prays to Brahman to lead us from untruth (unbeing) to truth (being), from darkness to light and from mortality to immortality (1.3.28). The wisdom, imparted by Eliot (1980) in "East Coker" in Four Quartets, dispels our illusion: "So the darkness shall be the light and the stillness the dancing" (p. 127). Darkness disappears at the appearance of light. In fact, there is no darkness. It is simply the absence of light. The stillness changes into the dancing (unlimited delight) at the dawn of knowledge.

Eliot holds the belief that there are three paths to achieve the Supreme Being or Brahman - action (karma), devotion (Bhakti) and knowledge (jnana). One can choose any path to achieve Brahman and moksha (liberation) according to one's interest and capacity. The path of knowledge is direct but difficult whereas the path of karma and devotion are easier but indirect. However, all the paths, according to the Prashna Upanishad, lead to Brahman as all types of rivers, flowing with an aim towards the ocean, enter and disappear into it destroying their name and form, now being identified as the only name of the ocean (6.5).

Despite this fact, one has to cross all three paths one by one to strengthen his spiritual practice. One should first purify his misdeeds by selfless action, then purify his heart by devotion and finally remove his ignorance by knowledge - to realize the Ultimate Truth. For spiritual progress, one should start acting without attachment in the initial stage. Slowly and slowly, action without attachment develops into devotion, which in turn develops into knowledge. From this viewpoint, action and devotion are means to achieve knowledge. Therefore, it is necessary to act without attachment and without expecting any fruit of action in the initial stage. One can practice all three paths together. Including all these three 
paths, Eliot (1980) says that one need to practice "prayer, observance, discipline, thought and action" (136) for the self-realization of the Essence (Brahman). Prayer is related to the path of devotion. Observance and action are related to the path of action. Discipline and thought are related to the path of knowledge.

Eliot's (1980) philosophical poems such as "The Dry Salvages" is action-oriented, "The Rock," devotion-oriented and "Little Gidding," knowledge-oriented. "The Dry Salvages" tells us, "And do not think of the fruit of action. / Fare forward" (p. 134). In fact, this is the message of the Bhagavad Gita (2.47). "The Rock," Eliot's short poetic play, is a symbol of God or Brahman. In its concluding lines, Eliot (1980) praises the glory of God: "we thank Thee that darkness reminds us of light. / O Light Invisible, we give Thee thanks for Thy great glory!" (p. 114). Here, the references to darkness and light remind us of the mantra of the Chhandogya Upanishad, which declares that Light is the dispeller of ignorance (3:17:8). God is Light, which is Invisible but "everything becomes enlightened in His light (Katha 2.2.15). Similarly, the Goddess of Darkness destroys the ignorance-darkness of the jivas (individual creatures) by Her light full of knowledge-jyotishaa baadhate tamah - as written in "Vedoktam Raatrisooktam" (verse 2) in the Rigved 10.10.127.2 (Datta, p. 41).

Though Eliot talks about the path of action and the path of devotion, yet he gives more importance to the path of knowledge. The concluding line of every poem generally holds much significance. Therefore, the concluding line of Eliot's (1980) last poem "Little Gidding" is worth considering, which says: "And the fire and the rose are one [and the same]" (p. 145). Here, Eliot attaches more importance to knowledge than action and devotion. This line reminds us of the non-dual wisdom of the Chhandogya Upanishad 3:14:1, which declares, "Verily, this whole world is Brahman" (Radhakrishnan, 2012, p. 391). This wisdom evokes the sense of non-dualism, humanism, cosmopolitism, equality and impartial justice. Eliot's fire and rose stand for the opposing parts of the reality, which lose their differences and become one in the eyes of knowledge.

Finally, Eliot makes an appeal to follow the human, moral, religious and spiritual values of life of the ancient time. These values are described by the Brihadaranyaka Upanishad, which narrates a Hindu mythological 
story, according to which, Prajapati (the Creator) tells his three groups of disciples - gods, men and demons to observe the three cardinal virtuesself-control (dama), charity (daana) and compassion (dayaa) respectively for their wellbeing (5.2.1-3). The people of The Waste Land are desperate because of the devastating results of World War I, modernity, the scientific materialism, the loss of faith in religion, the rising effect of the Industrial Revolution and the gross material thinking. Now, they are in a dire need of peace and happiness. To attain to the infinite and everlasting peace followed by unlimited happiness, Eliot (1980) tells people, in the final stanza of The Waste Land, to be generous, to be compassionate and to be self-controlled"Datta. Dayadhvam. Damyata" (50). This message echoes the story of the Brihadaranyaka Upanishad (5:2:1-3).

\section{CONCLUSION}

There are the echoes of the vision of Hindu philosophy in Eliot's writings such as in his important essay "Tradition and the Individual Talent," and in his important poems "The Love Song of J. Alfred Prufrock," "Gerontion," The Waste Land, "Ash Wednesday," "A Song for Simeon" and Four Quartets, which consists of four poems such as "Burnt Norton," "East Coker," "The Dry Salvages" and "Little Gidding." His writings echo the vision of the Hindu (Vedic) philosophy such as the Upanishads, the Bhagavad-Gita and the Patanjlai's Yoga Sutras with their significance for human life.

The search of the soul for peace, happiness, liberation and Brahman or God is the basic vision of Eliot's writings. Poet is a catalyst like "the still point" (Brahman). The poet's vision is close to the divine one. Time is both transitory or finite, and everlasting or infinite as well. Death is a part of the transitory time. The transitory time is a part of the ever-flowing eternal Time (Brahman). Consciousness means Brahman or his power, which is achieved by devotion and knowledge. One cannot attain to the knowledge of Brahman by ego. He who says that he knows Brahman does not know Him in reality. Brahman is beyond words or discourses. Therefore, Brahman can be known only through the self-realization. Humbleness or meekness is required to know the Essence or the Reality. Ignorance is the cause of one's ego and vanities. 
Eliot's writings are extremely influenced by the non-dual thoughts of Hindu philosophy. From the sense of non-dualism, time is one, which moves on a cycle, unlike the linear principle of time of the European mind. Therefore, birth and death, or creation and destruction are circular and move on the wheel of Time. There is no death of the soul. Death of the body is just the transformation from one state to another. Henceforth, death is an illusion and immortality is the reality. Eliot speaks for performing selfless and disinterested karma (actions), which is the seed of satisfaction. We need to be free from the fire of lust, desire, anger, avarice, infatuation, delusion, ego, jealousy, passion and cravings to refine the soul. For the betterment of the soul, we can follow any of three paths - the path of action, the path of devotion or the path of knowledge. However, the path of knowledge is more desirable because it is direct, though it demands austerity.

One's present life is determined by his past karma. No one can escape from the result of his karma. Passions and desires are transitory. Hence, they are not worth nourishing. Modern people living in the wasteland are morally and spiritually degraded and bankrupt due to the influence of the rise of the scientific materialism, hedonistic thinking and the loss of the ancient values of humanity, morality and spirituality.

Liberation is only a solution to the human suffering and bondage of life and death. Life is impermanent, changeable, transitory and full of sufferings. Therefore, liberation or salvation should be sought before death. When we are free from the myriads of our desires, we are liberated and attain to "Shantih" (peace).

We die and reborn every moment according to our bad or good deeds. Through spiritual practices, we can transcend time and attain to liberation. Jivatma (the individual self) and Paramatma (the Supreme Self) are like the two amicable birds living in the two branches of the same tree. But the jivatma cannot see Paramatma because there is a veil of Maya (ignorance, avidya) between them. However, the jivatma can see Paramatma and achieve peace and joy if he puts asunder the veil of Maya through the spiritual means of "prayer, observance, discipline, thought and action." Paramatma or Brahman is Light, the dispeller of ignorance. All is 
created by Brahman. Therefore, even the conflicting objects like "the fire and the rose are one." In reality, all are Brahman. Hence, all are one. This principle echoes the non-dual thoughts of Hindu philosophy. Finally, Eliot tells humanity to be generous, kind and self-controlled for the attainment of peace, happiness, Brahman/God and liberation.

Though the Westerners refuse that Eliot's main intention was to assimilate the Vedic teachings of the Hindu philosophy like the Upanishads, yet the dominant influence of the Oriental philosophy on his major poems and plays cannot be refuted. That he was a student of the Eastern philosophy at Harvard is as clear as the day.

In my opinion, Eliot suggests that it is necessary to lead the life of virtues, confirming to the ancient humanitarian, moral, religious and spiritual values of life as envisioned in Hindu philosophy, for the attainment of perpetual peace, unbound happiness, Brahman or God and liberation. Materiality should be utilized, not misused, as a means to achieve the ultimate goal of life, that is, the liberation from the bondage of life and death, and the liberation from desires, sufferings and sorrows.

The poems and plays of Eliot, unexplored by this paper, could be analyzed from the viewpoint of any one or all the eleven principal Upanishads of Hindu philosophy. They could be analyzed from the perspective of the Bhagavad-Gita or the Patanjali Yoga Sutras, too. There are very few scholars who have tried to analyze Eliot's works from the non-dual perspective of the Upanishads. It would extend the frontier of our knowledge and help to understand Eliot and his works better in a new light if they could be viewed from the Hindu philosophical thoughts, especially the Upanishadic ones.

\section{REFERENCES}

Baidya, B. (2014). (Trans.). The Bhagavad Geeta: The Song Supreme. Bhaktapur, Nepal: Sanatan Foundation.

Bhagavad Gita, or the Song Divine. (2003 B. S.). Gorakhpur, India: Gita Press.

Datta, R. (2050 B. S.). (Trans.).Vedoktam Raatrisooktam. In Shree Durgaasaptashatee (pp. 41-42). Gorakhpur, India: Gita Press.

Eliot, T. S. (1980). The complete poems and plays: 1909-1950. New York, USA: Harcourt Brace \& Company. 
---. (1921). Tradition and the individual talent. In The sacred wood (pp.4253). New York, USA: Aflred A. Knopf.

Moody, A. D. (2008). Tracing T. S. Eliot's spirit (digitally printed version). New York, USA: CUP.

Oldmeadow, H. (2004). Journeys east: 20th century western encounters with eastern religious traditions. Bloomington, Indiana: World Wisdom, Inc.

Prabhavananda, S., \& Isherwood C. (2015). (Trans.). Patanjali Yoga Sutras [Patanjali's Yoga Aphorisms]. Chennai, India: Sri Ramkrishna Math.

Radhakrishnan, S. (Ed. \& Trans.). (2012). The principal Upanishads. NOIDA, India: HarperCollins Publishers.

Shakaracharya. (2015). Vivekachudamani [The Crest-Jewel of Wisdom] (Svami Madhavananda, Trans. with notes and index). Kolkata, India: Advaita Ashrama.

Smidt, K. (2016). Poetry and belief in the work of T. S. Eliot (Routledge Library Editions: T. S. Eliot, vol. 7). New York, USA: Routledge. 